Dinara SIKHIMBAYEVA, doctor of Economics, professor, Karaganda University of Kazpotrebsoyuz, 100009, Kazakhstan, Karaganda, Academic 9, sdinara2007@yandex.ru, +77212441634

Olga ERMAKOVA, master student, Karaganda University of Kazpotrebsoyuz, olya.ermakova.64@mail.ru

\title{
DIRECTIONS OF DEVELOPMENT OF STRATEGIC MANAGEMENT OF THE HEALTHCARE SYSTEM OF THE REPUBLIC OF KAZAKHSTAN
}

The state and possibilities of improving strategic management in healthcare in Kazakhstan are investigated. The directions of the development of the strategic management of the health system of the Republic of Kazakhstan and the assistance of e-health in their achievement are determined.

Keywords: Strategy, strategic management, medical services, healthcare, digitalization

Динара СИХЫМБАЕВА, экономика вылымдарының докторы, профессор, Қазтұтынуодавы Қараванды университеті, 100009, Қазақсттан, Қараганды к.., Академическая 9 , sdinara2007@yandex.ru,+77212441634

Ольга ЕРМАКОВА, магистрант, Қазтұтынуодагы Қараванды университеті, olya.ermakova.64@mail.ru

\section{ҚР ДЕНСАУЛЫҚ САҚТАУ ЖУЙЕСІН СТРАТЕГИЯЛЫҚ БАСҚАРУДЫ ДАМЫТУ БАҒЫТТАРЫ}

Қазақстанның денсаулық сақтау саласындағы стратегиялық басқаруды жетілдірудің жай-күйі мен мүмкіндіктері зерттелді. ҚР Денсаулық сақтау жүйесін стратегиялық басқаруды дамыту бағыттары және е-Денсаулық сақтау саласына қолжеткізуге жәрдемдесу айқындалды.

Түйінді сөздер: Стратегия, стратегиялықбасқару, медициналыққызметтер, денсаулықсақтау, цифрландыру.

Динара СИХИМБАЕВА, доктор экономических наук, профессор, Карагандинский университет Казпотребсоюза, 100009, Казахстан, г, Караганда, Академическая 9, sdinara2007@yandex.ru,+77212441634

Ольга ЕРМАКОВА, магистрант, Карагандинский университет Казпотребсоюза, olya.ermakova.64@mail.ru

\section{НАПРАВЛЕНИЯ РАЗВИТИЯ СТРАТЕГИЧЕСКОГО УПРАВЛЕНИЯ СИСТЕМЫ ЗДРАВООХРАНЕНИЯ РК}

Исследовано состояние и возможности совершенствования стратегического управления в здравоохранении Казахстана. Определены направления развития стратегического управления системы здравоохранения РК и содействие е-здравоохранения в их достижении.

Ключевые слова: Стратегия, стратегическое управление, медицинские услуги, здравоохранение, цифровизация.

Statement of the problem. Improving the strategic management of public health organizations is an important area and is becoming increasingly important for the development of the health sector.

The development of healthcare as an economic system takes place in accordance with the economic and social processes that reflect the general trends in the formation of market relations in the Republic of Kazakhstan. However, the discrepancy between the real needs of the health system and the level of its financing with objective necessity requires finding ways to overcome this discrepancy in order to ensure a balance between the medical and economic components. Therefore, in modern conditions, the development and implementation of the company's development strategy is the most important condition for improving the efficiency of its activities, competitiveness and stability in the dynamically complex economic environment of the market.

The objective need for integration into the global economic space requires enterprises to use modern strategic planning tools to ensure a high level of economic efficiency and competitiveness in the production of high-quality products or services, as well as readiness for timely innovative changes. In the context of global economic instability, most 
Kazakh enterprises, unfortunately, do not apply methods and tools for managing external risks and timely responding to changes in macroeconomic conditions.

In the conditions of instability of the market economy, tougher competition, increasing consumer demands for the quality of products (services), an important place in the management of the enterprise is given to the development and implementation of a strategy focused on the formation of competitive advantages, methods and methods of competition that would allow the enterprise to operate long-term and sustainably in the market.

In the context of increasing competition and the rapid growth of high technologies, the role of system analysis of the external and internal environment, predictive research, and the search for opportunities for innovation is repeatedly increasing in the development of enterprise development strategies.

Based on the above, the task of developing scientifically-based methods and tools for strategic planning of effective development of enterprises based on continuous monitoring of external and internal environment factors using generalized systems of performance indicators is an urgent scientific task that has significant practical significance for the economy of the Republic of Kazakhstan in the context of globalization and financial and economic instability. Therefore, the study of the problems of strategy formation in enterprises is among the most relevant and paramount both in economic science and in economic practice.

Currently, the world and domestic economic science is intensively developing research aimed at forming strategies and strategic behavior of enterprises in a rapidly changing environment. However, most of these studies are descriptive in nature, and only a small number of papers contain specific guidance material.

Analysis of recent research and publications. The theoretical and methodological basis of the master's thesis research is based on the fundamental provisions and theoretical developments of domestic and foreign economists in the field of strategic management of enterprises, practical experience in the formation and implementation of enterprise development strategies.

Aspects of the theoretical nature of strategic management are presented in the works of many authors, such as R. Akoff, I. Ansoff, F. Kotler, M. Mescon, G. Mintzberg, M. Porter et al.

Among the researchers who dealt with theoretical issues in the field of competition and strategic management, it is necessary to distinguish: Novoselov A.S., Faleev A.V., Miles R.E., Snow
C.C., Zapour A., Khatony A., Kianipou N., Jafary F., Daudi O. Simba, Michel Sandler, Travis Good [1, 2, 4-7] and others.

The works of Hooly G.J., Lynch J.E.and Jobber D.[3] are devoted to the problems of management.

Highlighting previously unsolved parts of the overall problem. Despite the deep theoretical study of the formation and implementation of enterprise strategies, the practical aspects of this problem remain poorly understood. Therefore, scientific research is needed on methodological support for the development and implementation of strategies in accordance with the peculiarities of the functioning of enterprises in a competitive environment. The lack of practical study and methodological support of the above issues predetermined the choice of the research topic, the setting of goals and objectives, the logic and structure of the study.

In this regard, it is relevant to analyze the existing strategic tools aimed at improving the efficiency of the enterprise and the search for new methodological approaches to managing the development strategy of economic entities, taking into account the state of the external and internal environment, the current situation in Kazakhstan and the world market.

The purpose of the article is to develop recommendations for ensuring effective functioning and strategic management based on the materials of the healthcare system of the Republic of Kazakhstan.

Main results of the study. Today, digitalization in healthcare in Kazakhstan is one of the priority tasks. The urgency of digitalization issues is dictated by the growing demand of citizens for high-quality medical care. Improving the quality of medical services requires the priority development of e-health and the transition to paperless document management. Kazakhstan has adopted the State Program for the Development of Healthcare of the Republic of Kazakhstan for 2020-2025, the purpose of which is to provide high-quality and affordable healthcare. One of the main focuses of the Program will be to strengthen the health of children, adolescents and young people by preventing diseases, providing timely care and full rehabilitation, taking into account the best international practices, in accordance with the approaches in the UNICEF Health Strategy for 2016 -2030 .

Currently, thanks to modern technologies, centralized registers have been formed, which are necessary for the exchange of data on medical care provided. Standards have been approved to ensure uniform approaches to the development of the information and communication technologies in 
digital healthcare. The development of the healthcare integration platform has been completed. The development of information systems has expanded the range of automated public services, reduced paper document flow in medical organizations, and improved the quality of information about medical and pharmaceutical services. However, all these processes at the same time will not cancel the traditional trip to the polyclinics. People who are used to seeing doctors in person will also still be able to go for consultations.

Medicine is far ahead of many other areas in the development of technology, and the changes that these technologies bring are noticeable to many, because they allow earlier detection of diseases, prevent their development, give access to medicine to more people and, ultimately, improve the quality of life of people. The domestic healthcare system should move from expensive treatment of diseases to their prevention and management of public health. Modern healthcare should focus on disease prevention, rather than expensive inpatient treatment. It is necessary to practice the introduction of the services of "smart medicine", remote prevention and treatment," electronic medicine". These new types of medical services are especially in demand in such a large country as Kazakhstan. Digital solutions provide an opportunity to introduce new technologies that allow remote monitoring of the patient's health. Similar methods of patient monitoring are implemented in the OECD countries.

The quality of medical services is an essential component of the social well-being of the population. And first of all, the availability and quality of medical care, as well as issues of disease prevention, are important here. The introduction of digital technologies in healthcare will help solve first of all, improving the quality of medical services requires the development of e-health and the transition to paperless document management. All this will enable medical organizations in Kazakhstan to be ready for the introduction of mandatory social health insurance, and will also strengthen the activity of the population in managing their own health, increase confidence in health services, and optimize public spending on medical care.

Digital modernization of healthcare is currently considered as one of the main mechanisms for the modernization of domestic healthcare. At the same time, despite the obvious success of individual projects, the mass implementation of digitalization methods in the daily work of most health care institutions in the country remains insufficient. The main problems are the lack of a clearly regulated financing mechanism and regulatory support for digitalization, a scientifically based algorithm for the use of electronic technologies, a shortage of technical equipment and trained personnel.

Taking into account the current trends in the functioning of the sector under study and the current macroeconomic situation, it is necessary to improve the processes and mechanisms of strategic management. Kazakhstan can successfully cope with new global challenges and threats by establishing itself as an attractive country, applying strategic planning and forecasting as a set of interrelated management processes.

Conceptual planning of e-health is carried out in accordance with WHO recommendations. To identify the main conceptual solutions in the field of e-health, the main priorities of the health sector were identified, expressed in strategic documents and other decisions at the state level.

The general approach to drawing up the Concept of e-health development combines the idea of project/ program planning with the alignment of information and communication technologies (ICT) needs to the needs of the subject area (in this case, health).

The planning process from the impact to the necessary inputs for teaching this impact is considered on two levels:

- at the health level;

- at the e-health (ICT) level.

At the health level, the main directions of development and goals of health care are considered, and health needs that can be met or supported through e-health care are identified.

International experience shows that information systems in healthcare are gradually becoming not just a passive tool for providing accumulated data, but also a mechanism for preventing medical errors and a platform for teaching and disseminating new clinical knowledge, best practices and experience.

Decisions of Kazakhstan and the developed regulatory documents should be implemented in a timely, methodologically and technically competent manner in health information systems and in other processes necessary for the quality implementation and support of e-health components.

To achieve this effect, it is necessary to change the approaches to the implementation of e-health. It is critical to ensure the broad involvement and commitment of stakeholders, and especially domain specialists, at all stages of development, including:

- definition of goals, objectives and indicators for e-health initiatives of the Republic of Kazakhstan; - development, implementation and updating of standards and regulatory framework;

- identification of the needs for informatization of specific business processes, services and services; 
- defining requirements for the functionality and information architecture of the software;

- testing and participation in software acceptance;

- evaluating the effectiveness of e-health initiatives and their impact on the health system.

The institutional and implementation readiness of a wide range of stakeholders, including developers and suppliers of information systems and e-services, to actively participate in the process of forming ehealth requires the formation of a policy of involvement, sustainable financing and incentives from the Government of the Republic of Kazakhstan.

An important issue that requires urgent attention is ensuring the interoperability of health information systems, i.e. the possibility of exchanging clinical and non-clinical data while maintaining semantic continuity. With the spread of e-health systems throughout the country, the need to interact with the information systems of private and departmental medical and pharmaceutical organizations, and other state bodies, will become more and more intense. The lack of standards and a clear regulatory framework in the field of e-health in the medium and long term will lead to the chaotic development of high-tech solutions in an unregulated environment, and as a result will become a critical factor hindering successful development and sustainability at the national level.

The new vision of the functional architecture is determined by the needs of stakeholders, both in information and in the automation of processes, as well as the overall goals of the health system reflected in the program documents. The main stakeholders in this process are:

- consumers of medical services and medical professionals who directly provide medical care;

- managers at the local, regional and national levels.

Stakeholders define the objectives and functionality of each e-health component, as well as measurable outcome indicators that reflect the real impact on public health. Depending on the tasks and functionality, a conceptual framework is defined that provides a unified understanding of the process by all participants, as well as the structure and content of the necessary data (information model), primarily for the key element of e-health: the electronic health passport.

The general needs, the implementation of which will contribute to the development of all areas of the above-mentioned strategic documents, are as follows:

- Ensuring high-performance, safe and reliable communication between participants in the health care process;
- Providing accurate and timely statistics and analytics, as well as indicators for making the right decisions.

In order to ensure the sustainable development of the health system, the strategic management of human resources of the industry will be implemented. This implies synchronizing human resources management programs with the strategic goals of the industry development:

- development of public health,

- integration of health care around the needs of the population based on the priority of primary health care,

- modernization of medical and pharmaceutical education,

- development of innovations and medical science.

They will improve:

- system for determining the need,

- accounting and planning of human resources of health care,

- improve the efficiency and availability of health workforce resources,

- develop a system of independent assessment of knowledge and skills.

As a result of the review of the current state and prospects for the development of the healthcare system using digital technologies in the Republic of Kazakhstan, the following conclusions are made:

- the development of ICT, including in the health sector, is a priority strategic direction;

- high level and preparation of regulatory regulation of the healthcare sector;

- e-health is developing through centralization, but with insufficient involvement of end-users of information systems in the decision-making process;

- the emphasis in the implementation of information systems is placed on the collection of analytical information for making managerial and financial decisions, at the expense of functionality and information that allows healthcare professionals to provide safe, high-quality, timely and affordable medical services;

- the opportunity to attract private investment from business partners, including foreign ones, in the development of e-health on the principles of publicprivate partnership at the central and regional levels. These steps, together with new approaches in the field of healthcare informatization, implemented in accordance with the development concept and state programs, will allow us to modernize e-health in the coming years to meet the needs of patients and healthcare professionals, which, in turn, will increase the availability and quality of medical services.

The targeted allocation of funds for investment costs for the digitalization of healthcare is not provided, and therefore it is not possible to calculate 
the amount of funds. However, the digitalization of healthcare will use private sector incentives to encourage IT companies to independently invest in digitalization, including through public-private partnerships.

Planned effects of digitalization:

- savings of about KZT187,000,000 on the purchase of paper, on medical paper documentation;

- reduction of the number of purchased medical supplies. images (fluorography, X-ray, mammography, etc.) for KZT2,165,600,000;

- reduction of blood collection processing time by 2,5 times (by $60 \%$ ) due to electronic services;

- reduction of the time for obtaining the results of laboratory tests due to electronic services by 5 times (by $80 \%$ );

- reducing the time when assigning referrals for laboratory and diagnostic tests due to electronic services by 4 times (by $75 \%$ );

- reduction of the time for processing home call services (by $80 \%$ ) by 5 times;

- reduction of time when making an appointment with a districts doctor (by $80 \%$ ) by 4 times, when making an appointment with narrow specialists - by $86,6 \%$ (by 7 times) due to electronic services.

The simplest example of how digitalization affects the process of providing medical care is the use of mobile applications, thanks to which patients do not need to repeatedly come to a medical organization to receive laboratory results, as they become available on a smartphone. This is not just saving the patient's time, but also reducing queues and the employment of medical staff. A similar effect can be achieved with the use of telemedicine systems, both for the purposes of remote counseling, and for monitoring chronic conditions. Expert systems and artificial intelligence that assist medical personnel in making a diagnosis and prescribing treatment can improve the quality and safety of medical care.

Thus, based on the conducted research, it can be said that the use of information and communication technologies in health care is an urgent issue that needs to be addressed at the national level. A comprehensive strategic approach is needed, including legislative, institutional and technical measures to overcome the problems associated with this process.

The current e-health development strategy of the Republic of Kazakhstan was able to lay a certain foundation for further development. At the same time, the transition to a qualitatively new level of application of digital technologies requires improving the national strategy, ensuring its compliance with the current priorities of the health system and the accumulated scientific and practical knowledge, taking into account international experience.

The full digitalization of the healthcare system is a long-term goal. According to analysts ' forecasts, as part of the digital transformation, not only new professions will appear, but also the requirements for representatives of classical specialties will change. The IT sector is currently the fastest growing, and what is an innovation in it today will become obsolete tomorrow. Given all this, it is difficult to information and communication technologies the achievement of some final stage, when it will be possible to conclude that the system is fully digitized. The criteria used in international practice for the" digitalization" of health care are constantly changing in the direction of complication, and the task is not so much to achieve a conditional maximum, but to constantly develop.

Conclusion. In modern conditions, the development and implementation of the company's development strategy is the most important condition for improving the efficiency of its activities, competitiveness and stability in the dynamically complex economic environment of the market.

The role of strategic management is particularly important in today's world, where competition is "acute" and conditions change rapidly, so organizations must not only focus on internal conditions, but also develop long-term action strategies, as well as monitor changes in the environment. When choosing a strategy, it is important to determine which factors - economic, political, social, scientific, and technological-will influence the long-term development of the organization.

The mechanism of strategic management of enterprises in various sectors of the economy should take into account the main trends and features of industrial development, as well as be adapted to modern business conditions. These conditions confirm the improvement of the processes and mechanisms of strategic management of enterprises, industries and complexes, as well as the feasibility of further research in this area.

Today, the health sector faces complex and interrelated challenges, so effective results require a multi-pronged approach based on cooperation and the use of modern technologies. Among the potential solutions are increasing the availability of medical services through the formation of a dual system of public and private healthcare, as well as the use of modern virtual healthcare technologies.

In the theory and practice of strategic management, there are many tools and methods, each of which has its own advantages and disadvantages, as well as specific application conditions.

Strategic management of state medical organizations is expressed in the achievement of 
strategic goals, which are to increase and improve the health of the population, which in turn contributes to an increase in labor productivity. With regard to the methods of strategic management in the health system, the assessment of the strategic management of public health programs consists in the implementation of target indicators and the achievement of the strategic goals set out in this program. Evaluation of the effectiveness and efficiency of strategic government programs takes into account:

- the level of achievement of goals and immediate results in general;

- the level of compliance with the planned volume of strategic resources;

- the level of events and results achieved.

The data for the implementation of the method are all possible social and economic indicators, as well as statistical data on state programs.

The development of healthcare as an economic system takes place in accordance with the economic and social processes that reflect the general trends in the formation of market relations in the Republic of Kazakhstan. However, the discrepancy between the real needs of the health system and the level of its financing with objective necessity requires finding ways to overcome this discrepancy in order to ensure a balance between the medical and economic components. Therefore, in modern conditions, the development and implementation of the company's development strategy is the most important condition for improving the efficiency of its activities, competitiveness and stability in the dynamically complex economic environment of the market.

\section{References:}

1. Novoselov A.S., Faleev A.V. (2020) Issues of estimating indicators of regional strategic planning of socio-economic development. // Regional economy and management: electronic scientific journal.№1 (61). https://eee-region.ru/article/6101/

2. Miles R.E., Snow C.C. Organizational Strategy, Structure and Process. New-York: McGrow-Hill, 1978.

3. Hooly G.J., Lynch J.E., Jobber D. Generic Marketing Strategies // International Journal of Research in OECD Health Policy Studies. Strengthening Health Information Infrastructure for Health Care Quality Governance. - 2013. - 184 p.

4. Zapour A., Khatony A., Kianipou N., Jafary F. Identification and Analysis of Labor Productivity Components Based jn ACHIEVE Model // Global journal of health science. - 2015. - №1. - p.315.

5. Daudi O Simba. Application of ICT in strengthening health information systems in developing countries in the wake of globalization // African health sciences. US National Library of
Medicine National Institutes of Healht. NCBI. Makerere Medical School. - 2004. - Vol.3, №1. C.PMCID:PMC2688333

6. Michel Sandler. Outsourcing medical staffing: Hospitals turn to managed-service provider to handle all temporary staffing chores // Modern Health Care. http://www.modernhealthcare.com/ article/20151107/MAGAZINE/311079981

7. Travis Good. The Advantages and Measures of Outsourcing in Healthcare // Datica Health, Inc. https://datica.com/bog/the-advantages-and-measures -of-outsourcing-in-healthcare. 
